\title{
Effect of Harvesting Stage on Proximate Composition and Mineral Content of Portulaca quadrifida L. Grown in Metekel, Western Ethiopia
}

\author{
Dessie Almaw Cherie*, Lejalem Abeble Dagnaw \\ Ethiopian Institute of Agricultural Research (EIAR), Assosa Agricultural Research Center, Assosa, Ethiopia \\ Email address: \\ dalmaw121@gmail.com (D. A. Cherie) \\ ${ }^{*}$ Corresponding author \\ To cite this article: \\ Dessie Almaw Cherie, Lejalem Abeble Dagnaw. Effect of Harvesting Stage on Proximate Composition and Mineral Content of Portulaca \\ quadrifida L. Grown in Metekel, Western Ethiopia. Journal of Chemical, Environmental and Biological Engineering. \\ Vol. 5, No. 1, 2021, pp. 5-8. doi: 10.11648/j.jcebe.20210501.12
}

Received: February 4, 2021; Accepted: March 10, 2021; Published: March 17, 2021

\begin{abstract}
P. quadrifida is a juicy, mat-forming species and a widespread weed, which is highly appreciated for its high nutritional and medicinal value. It has been used as a nutrition and medicine since thousands of years ago. This is an important wild herb naturally found as a weed in field crops found in the world especially in India. In Ethiopia, particularly in western part of the country, societies use this plant aerial part as a food without perceive the nutritional quality and its appropriate harvesting stage. This study aimed to evaluate the effect of three harvesting stage on proximate composition and mineral content of the vegetable. All extracts showed noticeable amount of moisture, ash, crude protein, crude fat, crude fiber, carbohydrate, and minerals content (Calcium, Magnesium, Phosphorus, Iron, Potassium, and sodium) of this vegetable at each optimum harvesting stage. The proximate composition and mineral content of this leafy vegetable aerial part was evaluated and the result of mean value obtained were showed as follow: moisture $(81.17-89.25 \%)$, crude proteins $(1.187-2.186 \%)$, crude fibers $(1.483-2.157 \%)$, ash $(1.814-2.41 \%)$, carbohydrates $(2.866-12.916 \%)$, crude fat $(0.117-0.16 \%)$ and food energy $(19.18-57.85 \mathrm{kcal} / 100 \mathrm{~g})$. The mineral contents were good with significant amount of $\mathrm{K}$ (211.70- 249), Ca (109.25 -133.21), $\mathrm{Mg}(63.04$ - 84.74), P (103.71 - 136.14), Na (61.96 - 83.90) and Fe (3.06 - 4.34) mg/100g of extracted sample. The studied vegetable has low fat content at all harvesting stage. The herb has energetic values of $57.85 \mathrm{kcal} / 100 \mathrm{~g}$ at post-flowering followed by pre-flowering with energy value of $30.39 \mathrm{kcal} / 100 \mathrm{~g}$ and flowering stage having the least energy value of $19.18 \mathrm{k}$ $\mathrm{cal} / 100 \mathrm{~g}$ in the food.
\end{abstract}

Keywords: Growth Stage, Minerals content, Portulaca quadrifida, and Proximate Composition

\section{Introduction}

African leafy vegetables are the cheapest and most willingly available sources of vitamins, protein, essential amino acids and minerals [1]. Traditionally, this vegetables are cooked and eaten as a delight in together with a starchy staple food, usually in the form of porridge [2].

The rural communities of developing countries depend on wild edible plants to meet their food supplies during periods of food shortage. The wild edible vegetable and herbal plants are mostly serving as supplementary foods in different parts of Africa [3]. Wild edible plants are nutritionally rich and can supplement vitamins and micronutrients content in particular.
These show that wild edible plants are essential components of many African diets, especially in period of drought and food shortage season $[4,5]$. In addition to their role in closing food gaps during periods of starvation or scarcity, wild edible plants play an important role as traditional medicine and in maintaining livelihood security for many people in third world countries $[6,7]$.

Portulaca quadrifida Linn belongs to Portulacaceae family. It is a small diffused, succulent, annual herb found throughout the tropical parts of India. Portulaca quadrifida is a prostrate, mat-forming annual or short-lived perennial herb with much-branched, spreading, articulated, fleshy stems up to $30 \mathrm{~cm}$ long or longer, rooting freely from the 
nodes, often flushed reddish; nodes with a dense whorl of whitish hairs [8]. The plant Portulaca quadrifida is commonly known as "Chicken Weed", [9] and named as "Kimma" locally; widely grows in most part of Ethiopia as a weed and vegetable in cultivated lands together with maize and sorghum. It is used as a vegetable and for various curative purposes. Aerial parts of the plant has been used for traditional medicine (such as anti-stomach ulcer) and nutrition for many years in Benshangul Gumuz, Ethiopia. The Shinasha and Gumuz societies have long history of using the fresh aerial parts of $P$. quadrifida as a raw vegetable sauce along with porridge and traditional thick fermented bread made from the flour of finger millet, maize sorghum or their mixture [10] locally known as chimbo or beddo. The societies have been using the plant without perceive its nutritional quality.

This study aimed to evaluate changes in proximate composition and minerals content of whole parts of $P$. quadrifida in relation to three harvesting stage using standard method of food analysis. The analysis of nutritional content for P. quadrifida give a baseline for further study. This herb has a potential to grow in most agro-ecology and environmental condition including desert area. This outcome provides a chance to increase the awareness of the people to cultivate the plant in small or large farms and use as a food in appropriate growth stage.

\section{Materials and Methods}

\subsection{Study Area}

The study was conducted at Assosa agriculture research center (AsARC) agricultural and nutritional research laboratories. The sample site is located in Benshangul Gumuz Regional State, which is $690 \mathrm{~km}$ in the west of Addis Ababa, Ethiopia. The research site is located between 09 49'92.9" and 09 49'95.1" North latitude and 34'42'32.8" and $34^{\circ} 42^{\prime} 58.3^{\prime \prime}$ East longitude, with 1413 to 1531 meter above sea level altitude.

\subsection{Materials}

Plant material (Portulaca quadrifida Linn), which was identified and authenticated by Bahir Dar University botanist, $\mathrm{pH}$ meter (model No $\mathrm{pH}-016$ Bench top $\mathrm{pH}$ meter), atomic absorption spectrophotometer (AAS), digital burette (model No 16G10518), Kjeldhal nitrogen distiller and digester, muffle furnace, dry oven (Model E028-230V-T), spectrophotometer, flame photometer, and electronic balance (model No $1 \mathrm{~A} 11003 \mathrm{~N}$ ) were major materials used for experimental analysis.

\subsection{Sample Collection and Preparation}

Representative samples were collected in three growth stage (pre-flowering, flowering and post-flowering) from Benshangul Gumuz regional state western, Ethiopia. The collected samples were washed to freed from any contamination, air dried, ground and sieved in 0.5 , and $2 \mathrm{~mm}$ sieve size and then mixed thoroughly to obtain a homogeneous envoy flour sample. The sieved $p$. quadrifida samples were packed and sealed in an airtight plastic cover and ready for proximate and mineral content analysis.

\subsection{Chemicals}

All chemicals; solvents, standards and reagents used in the study were German and Indian product analytical grade.

\subsection{Methods Used Proximate Composition Analysis}

The collected $p$. quadrifida samples subjected to the proximate analysis of percent of crude protein content, ash content, moisture content, crude fiber, crude fat content and carbohydrate content of prepared samples were determined in triplicate using micro kjeldhal method, dry ashing method, oven dry (at temperature $105^{\circ} \mathrm{C}$ ) method, Vacuum pump, sohxlet apparatus extraction method, and subtracting method from percent of moisture, fat, protein and ash respectively $[11,12]$. Total energy value of the food formulation was calculated according to the method using the formula [13].

\subsection{Elemental Analysis}

All elemental analyses were carried out in triplications. The results for mineral contents were expressed as $\mathrm{mg} / 100 \mathrm{~g}$ of sample. Calcium, magnesium, phosphorus, sodium, potassium, and iron contents of the $p$. quadrifida aerial parts were evaluated in this study. The calcium, magnesium, and iron contents were determined using atomic absorption spectrophotometer (AAS), potassium and sodium were determined using flame photometer whilst Phosphorus analysis was also done by spectrophotometer [14].

\subsection{Methods of Data Analysis}

All measurements were done in triplicate and reported as mean \pm SD (standard deviation). The statistical analysis was done using and SPSS 20 statistical analysis software.

\section{Results and Discussion}

Some of proximate composition and minerals content showed a significant interaction between analyzed parameters and harvesting stage. The percentage moisture content, ash content, crude fat, crude protein, crude fiber, carbohydrate and total energy of aerial part of $P$. quadrifida is presented in (Table 1). The percentage moisture content, ash content, crude fat, crude protein, crude fiber, carbohydrate and total energy of aerial part of $P$. quadrifida ranged from $81.17 \pm 2.68 \%$ (post-flowering) to $91.42 \pm 3.902 \%$ (flowering), $1.814 \pm 0.012 \%$ (pre-flowering) to $2.41 \pm 0.01 \%$ (post flowering), $0.117 \pm 0.033 \%$ (pre-flowering) to $0.16 \pm 0.034 \%$ (post-flowering), $\quad 1.187 \pm 0.031 \% \quad$ (post-flowering) to $2.186 \pm 0.05 \%$ (pre-flowering), $1.483 \pm 0.007 \%$ (pre-flowering) to $2.157 \pm 0.014 \% \quad$ (post-flowering), $2.866 \pm 0.792 \%$ (flowering) to $12.916 \pm 0.549 \%$ (post-flowering), and $19.18 \pm 1.09 \%$ (flowering) to $57.85 \pm 3.016 \%$ (post-flowering) respectively. 
Table 1. Mean proximate composition of aerial part of aqueous extraction of P. quadrifida at three growth stage (\%).

\begin{tabular}{llllllll}
\hline Growth Stage & Moisture (\%) & Ash (\%) & $\begin{array}{l}\text { Crude Fiber } \\
(\mathbf{\%})\end{array}$ & Crude Fat (\%) & $\begin{array}{l}\text { Crude Protein } \\
(\mathbf{\%})\end{array}$ & $\begin{array}{l}\text { Carbohydrate } \\
(\mathbf{\%})\end{array}$ & $\begin{array}{l}\text { Energykcal } \\
(\mathbf{1 0 0 g})^{-1}\end{array}$ \\
\hline Pre-Flowering & $89.25 \pm 3.107$ & $1.814 \pm 0.012$ & $1.483 \pm 0.007$ & $0.117 \pm 0.033$ & $2.186 \pm 0.05$ & $5.15 \pm 0.632$ & $30.39 \pm 2.12$ \\
Flowering & $91.42 \pm 3.902$ & $2.108 \pm 0.009$ & $1.831 \pm 0.018$ & $0.124 \pm 0.021$ & $1.651 \pm 0.008$ & $2.866 \pm 0.792$ & $19.18 \pm 1.090$ \\
Post-Flowering & $81.17 \pm 2.68$ & $2.41 \pm 0.01$ & $2.157 \pm 0.014$ & $0.16 \pm 0.034$ & $1.187 \pm 0.013$ & $12.916 \pm 0.549$ & $57.85 \pm 3.016$ \\
Mean & 87.280 & 2.111 & 1.824 & 0.134 & 1.675 & 87.280 & 2.111 \\
SD & 5.402 & 0.298 & 0.337 & 0.023 & 0.500 & 5.402 & 0.298 \\
\%CV & 6.189 & 14.119 & 18.483 & 17.261 & 29.852 & 6.189 & 14.119 \\
\hline
\end{tabular}

The values are expressed as means \pm standard deviations of triplicate analysis.

Proximate composition and energy in $\mathrm{kcal} / 100 \mathrm{~g}$ value differed at the studied harvesting stages. Particularly, plant contained more carbohydrate, ash, crude fiber and energetic value at the third harvesting stage; whereas highest crude protein content recorded at the first harvesting stage. Moreover, aerial parts of the plant had highest moisture content at the second harvesting stages which is at flowering stage. However, present study purslane proximate composition content is lower than that of portulaca oleraceae previous study [15], the data reveals better result. The analysis of all measurements were done in triplicate and reported as mean $\pm \mathrm{SD}$ (standard deviation).
The result of mineral content for selected herb is shown in Table 2. The mineral content of vegetables is influenced by the quantity and the availability of minerals in the soil. Calcium, iron and potassium content increase with harvesting stage; whereas magnesium and sodium decrease as the harvesting time increase. In the second harvesting stage phosphorus concentration in the aerial part of the plant were significantly higher, but in the third stage of growth content of phosphorus slightly declined. In this study, calcium was positively correlated with potassium, and iron, but negatively correlated with magnesium and sodium, and the result is agreed with previous study [16].

Table 2. Results mineral content of P. quadrifida at three growth stage ( $\mathrm{mg} / \mathrm{l00g})$.

\begin{tabular}{lllllll}
\hline Growth Stage & Calcium & Magnesium & Phosphorus & Iron & potassium \\
\hline Pre-Flowering & $109.25 \pm 2.77$ & $84.74 \pm 1.52$ & $103.71 \pm 2.87$ & $3.06 \pm 0.91$ & $211.70 \pm 7.140$ \\
Flowering & $127.02 \pm 3.28$ & $72.18 \pm 1.94$ & $136.14 \pm 2.02$ & $3.72 \pm 0.54$ & $230.80 \pm 5.76$ \\
Post-Flowering & $133.21 \pm 3.18$ & $63.04 \pm 1.03$ & $118.29 \pm 1.801$ & $4.34 \pm 1.08$ & $249.00 \pm 8.91$ \\
Mean & 123.160 & 73.320 & 119.380 & 3.707 & $61.96 \pm 1.02$ \\
SD & 12.438 & 10.895 & 16.242 & 0.640 & 72.09 & 18.652 \\
\%CV & 10.099 & 14.859 & 13.606 & 17.269 & 8.092 \\
\hline
\end{tabular}

The values are expressed as means \pm standard deviations of triplicate analysis.

\section{Conclusion and Recommendation}

In conclusion, early harvesting of the plant was recorded higher amount of protein and moisture content as well as post harvesting stage resulted in high ash, crude fiber and energetic value the reason might be source of protein is depending on nitrogen content and nitrogen is easily volatile through increasing of harvesting time. The values noticeably indicates that Post-flowering Portulaca quadrifida has higher percent of ash, crude fiber, crude fat, carbohydrate and energetic value, with lower percentage of moisture and crude protein. In this study, high amount of moisture content was recorded at flowering stage. The values of calcium, sodium, and iron at the mature post-flowering stage were higher than pre-flowering stage and vice versa for magnesium and potassium. As general the result of the study showed that the plant contains significant proximate composition and minerals content, and can be used as easily accessible source of food, natural antioxidant by cultivating at appropriate harvesting stage. The researcher concludes and recommends that the nutritional quality and mineral content of the plant is harvesting stage dependent the rational might be due to the interaction and redox reaction formation through time and societies find in the area should have to utilize this leafy vegetable in accordance with the appropriate harvesting stage.

\section{References}

[1] Martin, F. W. \& Meitner, L. S. (1998). Edible leaves of the Tropic, educational concerns for hunger organization.

[2] Vainio-Mattila, K. (2000). Wild vegetables used by the Sambaa in the Usambara Mountains, Tanzania. AnnalesBotaniciFennici, 37: 57-67.

[3] P. M. Mandu, G. W. Nagugi, and C. H. S. (1999). Kabuye, Traditional Food Plants of Kenya, National Museums of Kenya, Nairobi, Kenya.

[4] A. Tesfaye. (2007). Plant diversity in western Ethiopia. Ecology, ethnobotany and conservation $\mathrm{Ph}$. D. thesis], Faculty of Mathematicsand Natural Sciences, University of Osla, Norway.

[5] A. Getahun, (1974). "The role of wild plants in the native diet in Ethiopia," Agro-Ecosystems, vol. 1, pp. 45-56.

[6] Beluhan S. and Ranogajec A. (2010). Chemical composition and non-volatile components of Croatian wild edible mushrooms. Food Chemistry; 124: 1076-1082. 
[7] Afolayan A. and Jimoh F. (2009). Nutritional quality of some wild leafy vegetables in South Africa. International Journal of Food Science and Nutrition; 60: 424-431.

[8] Kiritikar, K. R. and Basu, B. D. (1933). Indian Medicinal plants, Vol. 111.

[9] Facciola, S. (1990). Cornucopia: a source book of edible plants. Vista, CA: Kampong Publications.

[10] Tariku B. and Eyayu M. (2017). Study on the Diversity and Use of Wild Edible Plants in Bullen District Northwest Ethiopia. J. Bot. Article ID8383468, 10 pages https://doi.org/10.1155 / 2017/8383468.

[11] William H (ed.), George W (ed.). Official method of analysis of AOAC international. 18th Edition. MARY LAND: AOAC international; 2005 available from: https://scholar.google.com/scholar?hl=en\&as_sdt $=0 \% 2 \mathrm{C} 5 \& \mathrm{q}=$ aoac + official + methods $\% 2$ C $2005 \& b$ tnG $=[$ accessed 25 th January 2019].
[12] Mohammed AS, H Ara, SA J, et al. (2004). Nutritional Composition and Stabilization of Local Variety Rice Bran BRRI-28. International Journal of Science and Technology. 3 (5): 306-313.

[13] Mahgoub SE. (1999). Production and evaluation of weaning foods based on sorghum and legumes. Plant Foods for Human Nutrition. 1; 54 (1): 29-42.

[14] AOAC (2000). Official Methods of Analysis. 17th Edition, The Association of Official Analytical Chemists, Gaithersburg, MD, USA. DOI: 10.4236/oalib.1105505.

[15] Abeer G. Almasoud and Eman S. (2014). Nutritional Quality of Purslane and its crackers. Middle East Journal of Applied Sciences 4 (3): 448-454, ISSN 2077-4613.

[16] Md. Kamal Uddin, Abdul Shukor Juraimi, et al. (2012). Evaluation of Antioxidant Properties and Mineral Composition of Purslane (Portulacaoleracea L.) at Different Growth Stages Int. J. Mol. Sci. 13, 10257-10267; doi: 10.3390/ijms130810257ISSN1422-0067 www.mdpi.com/journal/ijms. 